\title{
The Singer-Songwriter on Stage: Reconciling the Artist and the Performer
}

Rachel Haworth, University of Hull

\begin{abstract}
The singer-songwriter is a ubiquitous figure within popular music. Although the name may appear to simply refer to an artist who writes and performs his/her own material, it also signifies a web of assumptions around what constitutes quality and value within popular music. In the context of the European genres of the chanson française and the canzone d'autore, the singer-songwriter is conceptualised as a legend of his/her respective song form and a paradigmatic example of quality songwriting. Yet it is often the notion of the singersongwriter as artist which remains the focus of analyses of these figures. As a result, an important element of what it means to be a singer-songwriter can be overlooked: that is, the place of performance, the necessity for a singer-songwriter to appear live on stage and play and sing his/her songs in front of an audience. This article explores some of the apparent tensions inherent to this artist-performer paradox, by critically analysing examples of the singer-songwriters' performance styles in the context of the genre discourse which depicts them primarily as artists. It thus challenges the appropriateness of such conceptualisations when applied to the singer-songwriter on stage.
\end{abstract}

\section{Key Words}

Singer-songwriter; chanson française; canzone d'autore; performance

\section{Biography}

Rachel Haworth is Lecturer in Italian at the University of Hull, UK. Her research interests lie within the broad areas of French and Italian popular music. She has published on French popular music in 1968, media representations of Brassens, Brel and Ferré and the place of performance in the chanson française. She holds a $\mathrm{PhD}$ from the University of Leeds and this research is due to be published by Ashgate in a volume entitled From the chanson française to the canzone d'autore in the 1960s and 70s: Authenticity, Authority, Influence.

\section{Introduction}

The singer-songwriter is a ubiquitous figure on the global popular music scene. Although this label appears to refer merely to an artist who writes and performs his or her own material, it in fact connotes a web of assumptions around what constitutes quality and value within popular music. Roy Shuker points out that in the case of the singer-songwriter, 'an emphasis on lyrics has resulted in the work of such performers often being referred to as song poets, accorded auteur status, and made the subject of intensive lyric analysis' (Shuker 2002: 277). Ultimately, Shuker concludes that 'the concept of the singer-songwriter [... has] strong connotations of greater authenticity and “true” auteurship’ (Shuker 2002: 277). Whilst the 
terms 'authenticity' and 'true' are often used within popular music studies, their precise meanings remain subjective and fluid, yet nearly always signifying quality and the highest of standards. The identification of authenticity with the figure of the singer-songwriter imbues him or her with this same quality. The entry by John Potter on singer-songwriters in the Grove Music Online Database reinforces these connotations. He describes how singersongwriters have also been referred to as folk poet, auteur, poet-composer, and bard, and explains that their 'songs have the legitimacy of a poet reading his or her own verse, to which is added the authority of a musician singing an own composition' (Potter). The figure of the singer-songwriter, then, has become synonymous with legitimacy, authority and quality within popular music globally. Obvious examples of this phenomenon include Bob Dylan and Leonard Cohen.

A similar conceptualisation of the singer-songwriter can also be found within European popular music. Franz-Josef Degenhardt, Hanns Dieter Hüsch and Reinhard Mey from Germany, Victor Manuel from Spain, Georges Brassens and Jacques Brel from France and Fabrizio De André and Giorgio Gaber from Italy: all these singer-songwriters (and others) have come to represent the best that their national respective genres have to offer. ${ }^{1}$ This article focuses on two of these genres: the French chanson (or chanson française) and the Italian canzone d'autore. It uses the examples of Brassens, Brel, De André and Gaber to illustrate the ways in which the figure of the singer-songwriter is conceptualised within these two national contexts. These four men (in particular, although there are others) are conceptualised as legends of their respective song forms, paradigmatic examples of quality songwriting, chanson and canzone d'autore stars. ${ }^{2}$ Yet it is often their status as writers, creators and artists (in the sense that they are said to produce works of art) which remains the focus of analyses of these singer-songwriters and also of chanson and the canzone d'autore in 
general. As a result, an important element of what it means to be a singer-songwriter has often been overlooked: that is, the place of performance, and with it, the necessity for a singer-songwriter to appear on stage, live, in front of a paying audience and to play and sing the songs that he/she has written. Although the link between performance and the singersongwriter has been of increasing interest to academics, the study of performance has to go further and explore the impact performance has on celebrity, market value, popularity and the construction of a star persona. It is these elements of the conceptualisation of the singersongwriter which this article seeks to address. Specifically, it explores some of the tensions around the notion of performance that are embodied by the singer-songwriter, within the wider context of the discourse surrounding chanson and the canzone d'autore.

\section{Chanson and canzone d'autore discourse}

Thanks to the constitutive discourse of both chanson and the canzone d'autore, the dichotomy between 'song as art' and 'song as performance' is initially identified and then subsequently reified by many different writers, critics, journalists and even fans.

Significantly, the French term for singer-songwriter, auteur-compositeur-interprète [literally, author-composer-performer], suggests that performance is just as integral an activity as writing lyrics and composing music. As for the Italian term, cantautore [literally, author of songs], the notion of performance may first appear to be obscured in a mere reference to singing only, with the act of writing being much more prominent. But there is resonance here with the cantastorie, a traditional figure from Italian oral literature and popular culture, who would travel to different communities, sharing stories through songs, which were often accompanied by a guitar. This in turn points to performance as still being an integral part of a cantautore’s role. 
Yet the discourses of both genres do not reflect this balance between the lyrical, the musical and the performative that a singer-songwriter represents. This is particularly the case in examples of discourse produced during the period from the late 1950s to the early 1970s, when both of the genres in question can be considered to be in their prime. Here, conceptualisations of the auteur-compositeur-interprète and the cantautore focus on the importance of writing, of the singer-songwriter sincerely and genuinely sharing his life experiences in his songs, of individual creativity, inspiration and flair in the lyrics much more than the music, and of the motivation behind writing songs, which is nothing to do with the sordid business of earning money but comes rather from the desire to create a piece of art.

Vernillat and Charpentreau, in their publication La Chanson française from 1971, provide one such example of this type of discourse. Their description of chanson during the 1950s demonstrates some of the ways in which the singer-songwriter can be conceptualised:

[Les] auteurs-compositeurs ont apporté à la chanson des exigences de qualité accrue, rompant avec la banalité des rengaines fabriquées à la chaîne sur poncifs 'littéraires' ou 'musicaux' en des officines parfois spécialisés. Grâce à eux, la chanson est apparue comme un mode d'expression personnelle, au même titre que d'autres arts. Ils nous ont donné une chanson, simplifiée, débarrassée des flons-flons, des plumes et des grands spectacles, toute une 'sauce' qui tentait souvent de faire illusion pour enrober des morceaux indigents. (Vernillat and Charpentreau 1971: 86)

[The singer-songwriters have brought to chanson the demand for greater quality, thus breaking with the banality of those corny old songs, churned out by recording labels, and even by those specialist organisations, under the commonplace descriptors of 'literary' or 'musical'. Thanks to these singer-songwriters, chanson can be seen as a means of personal expression, on the same level as other art forms. These artists have given us a simplified version of song, free from pomp and circumstance, from the trappings of the grand spectacle which, like a sauce, mask even the weakest offerings.]

In this passage, there are several devices at work constructing chanson in a particular manner. The singer-songwriters are given credit for the perceived changes in chanson, which move the genre away from commerce and industry and which introduce a demand for better quality songs. The binary pairing of 'qualité' [quality] with 'banalité' [banality], and the negative 
connotations of ‘fabriquées à la chaîne’ [literally, manufactured on a conveyor belt] point to a hierarchy of value at work within this description, which places chanson firmly above other (allegedly inferior) forms of song, and the auteurs-compositeurs firmly above other singers and performers. Because the singer-songwriters write songs for purely personal reasons and are not motivated by the desire to satisfy audience demand, chanson can be classified as an art form.

This conceptualisation of the singer-songwriters' chansons as being of a higher standard, as not banal, clichéd or fabricated, as a mode of personal expression and ultimately as an art form and not a commercial product, suggests that only by conforming to such genre rules can a song be classified as the best example of chanson. The singer-songwriters themselves are regarded as producers of a higher-quality song form because they follow these rules, thus becoming paradigms of French songwriting.

In a similar way, Roberto Galanti, in an article entitled 'Piccola storia della canzone in Italia: gli anni d'oro dei cantautori', published in the journal Musica e dischi in 1964, seeks to construct the canzone d'autore according to a particular image of the genre. He describes the popular music situation in Italy during the period thus:

Fioriscono in Italia i cantautori, coloro che modernizzano definitivamente la canzone, riportandola su elevate toni artistici e poetici. Sono i loro anni d'oro, dove compongono i loro pezzi migliori, più freschi, più spontanei. Il campo musicale con essi si allarga notevolmente: nuovi temi, nuovi argomenti e, soprattutto, uno stile inconfondibile, creato finalmente senza copiare nessuno all'estero. (Galanti 1964: 14)

[The singer-songwriters are flourishing in Italy; that is, those who are definitively modernising song, lifting it to elevated artistic and poetic tones. These are their golden years, in which the best, freshest and most spontaneous pieces are being composed. Thanks to the singer-songwriters, the musical field is becoming noticeably wider: there are new themes, new arguments and, above all, an unmistakeable style, which, finally, is created from within, not copied from abroad.] 
Like Vernillat and Charpentreau's portrayal of chanson, Galanti's description of the canzone d'autore makes use of several devices which serve to construct the genre along specific lines. Above all, the canzone d'autore is seen as a development within Italian popular music. From the context of the rest of the article, the genre's ability to modernise is seen as positive. Writing during a period of economic growth, Galanti views the genre’s drive towards modernisation and innovation as symbolic of Italy's new economic prosperity. However, the innovations of the canzone d'autore in fact make use of art and poetry, two genres which, according to Galanti’s reading, would appear to be lacking within Italian popular music prior to this development. The use of such terms, together with the notion of elevation, suggests that the singer-songwriters have a role to perform as educators, both of their audience and of the music industry. Also, the high cultural connotations of 'artistici' [artistic] and 'poetici' [poetic] serve to valorise the genre and conceptualise it as more than a mere popular cultural product.

Such conceptualisations are clearly idealised ways of describing the two genres, and the activities of the singer-songwriters involved. If we take as an example the question of commercial success, there is clearly a paradox at work here: the ideal (where the singersongwriter shuns all forms of commercialism) cannot exist in reality (where the singersongwriter earns a living from his profession). Yet what is important is that these conceptualisations have become cemented in the popular imagination: it has become an accepted belief that a singer-songwriter is sincere, focuses on his lyrics and shuns profits. Georges Brassens, for example, explains that singer-songwriters are merely 'de pauvres connards devant des pieds de micro!' (Cristiani and Leloir 2003: 19) [poor bastards in front of a microphone!] and declares that 'c'est très emmerdant, cette histoire d'argent, parce qu'il y a beaucoup de types qui se lancent dans la chanson pour ça' (Cristiani and Leloir 2003: 34) 
[this story about money is really bloody annoying because there are lots of blokes who try their hand at chanson just for that]. Such comments reveal the extent to which the rhetoric surrounding the singer-songwriter values inspiration, creativity and hard work over commerce and sales, and the extent to which such rhetoric can be internalised by the singersongwriters themselves.

\section{Performance}

Yet these singer-songwriters (Brassens, Brel, De André, Gaber and others) are, amongst other things, performers. Significantly, this element is overlooked as far as the critical discourses of chanson and the canzone d'autore are concerned. For example, Vernillat and Charpentreau refer to the French singer-songwriters as auteurs-compositeurs, entirely eliminating interprètes from the label. Galanti is happy to refer to the musical, poetic and artistic innovations made by the Italian cantautori, but any advances made in performance again go unexplored.

Nevertheless it is impossible to ignore the performative aspect of these singer-songwriters' careers. As Avron White explains, 'although the musical product yields its greatest source of income in recorded and written form, its authenticity, or validity, is very much dependent upon the music's being on view in the live performance' (White 1987: 187). It is by seeing the singer-songwriter perform his songs that the audience can authenticate the music that they listen to, as the singer-songwriter is confirmed as author, composer and performer of his music (Auslander 1999: 78). As I have suggested elsewhere,

to be a singer-songwriter requires an engagement with the popular music industry. Signing a record deal, recording songs for album releases, performing in front of fans on stage, giving interviews to industry representatives, posing for photographs to be used as album covers: all of these activities (and many others) demonstrate the commercial and illusory nature of a singer-songwriter. (Haworth forthcoming: 2) 
In the context of performance, the singer-songwriters are required to engage further with the popular music industry and with commercial questions which are overlooked by the genres' discourse. They deliver concerts, for which the audience must purchase a ticket in order to attend, thus earning money for the singer-songwriter. They appear on stage and perform a selection of their songs, but the very act of performance embodies notions of fabrication, façade and the presentation of a 'false' persona to the audience. And they receive applause from their audience, who signal their enjoyment at the entertainment they have received and thus reaffirm the singer-songwriter's popularity. Yet popularity (in terms of record sales), personas (that is, presenting an identity to the audience which is not your true character) and performance (in terms of entertaining an audience and putting on a show) are not recognised elements of the conceptualisation of singer-songwriters in the discourse of the period, as previously illustrated. We have already examined some of the reasons for this: creativity, authorship and artistry are the most valued attributes that a singer-songwriter should be seen to represent. Performance, commerce and entertainment are often conceived of in opposition to such values by the constitutive critical discourses of the genres - yet all are central to being a singer-songwriter.

\section{Brassens and De André}

If we take the example of Georges Brassens, his performance style, on-stage persona and popularity are often downplayed by writers, critics and fans, who instead choose to focus on his lyrics, intricate wordplay, artistry and creativity. The foregrounding of the literary helps to legitimise Brassens as the creator of quality songs, which are conceptualised as more than mere of examples popular music and even folk culture, instead being classed as examples of high culture. The demotion of the physical and commercial aspects of Brassens cements this legitimation process - even though we can argue that Brassens is in fact a physical and 
commercially successful singer-songwriter. Significantly, what has been written about Brassens’s performances has focused on his intense discomfort at appearing on stage. Sara Poole describes him as a 'sweating, scowling colossus' (2000: 18). Descriptions of his early performances in 1952 focus on his physical appearance (with several references to Brassens’s moustache) and his nerves (words such as timid, shy, nerves and stage fright are common) (Bottet and Salachas 1989: 74). On stage, he would appear wearing a suit or jacket and trousers with a shirt and would stand in the spotlight with his guitar and the microphone. His poses appear natural and thus awkward (he is renowned for resting his foot on a chair, to balance his guitar, and then constantly fidgeting throughout his performance, attempting to become better balanced). The stage is bare except for a piano - which is only used as a table for Brassens’s glass of water. For television appearances and music videos, Brassens would still usually appear alone, with his acoustic guitar. When there is a second guitar player or a double bass player, he is mostly out of shot. The camera does the same job as the spotlight on stage, by remaining focused on Brassens, often using one shot and merely zooming in and then remaining on the singer-songwriter throughout the song. Whilst this style of filming is not unique to Brassens, it does appear to be the principal style used to film the singersongwriter. His are performances at their most basic, devoid of the commercial trappings of extravagant sets and scenery, natural, awkward and yet theatrical. As a result of Brassens’s position as a paradigm of his genre in chanson discourse, his performances take on a similar paradigmatic standing. Naturalness and awkwardness become the standard within chanson performances, as they support the rhetoric in the opinion that performance as a form of entertainment is to be avoided and so a singer-songwriter should not be comfortable on stage.

In a similar way, Fabrizio de André has been conceptualised as a paradigm of the canzone d'autore. Interestingly, De André's early performances are similar to those of Brassens. The 
singer-songwriter himself is always the main focus of attention, and De André often appears seated at the front of the stage with his acoustic guitar and a microphone. However, later in his career, there is often an elaborate range of supporting musicians behind him, playing woodwind, stringed and percussion instruments. The two singer-songwriters also have the same intensity on their faces whilst they are singing, serving to draw the audience into the performance and suggesting that they both work hard whilst on stage. Just as Brassens's voice is distinctively his, so De André's voice is easily identifiable:

De André - che quando canta in lingua ha una pronuncia da italiano colto, diventata solo negli ultimi anni (purtroppo) un elemento non neutro - ha un tratto distintivo incorporato, per così dire, nelle sue canzoni: è la risonanza del suo registro grave, legata all'estenzione molto caratteristica della sua voce. (Fabbri 2008: 159)

[De André, who when he sings has an educated pronunciation in Italian (which has only recently, unfortunately, become a non-neutral element), has a distinctive trait incorporated into his songs: it is the resonance of his serious register, linked to the characteristic extension of his voice.]

But it is by seeing De André perform his songs that the audience are able to authenticate and validate his as the voice that they have heard on records or on the radio.

De André is often likened to Brassens, particularly in terms of genre innovations and literary quality of the lyrics, as well as on stage performance styles. De André's early performances in particular are most comparable to those of the French singer-songwriter. Recordings of these performances are available on the Fabrizio De André boxset released by the Parole $e$ canzoni series, which produces collections of lyrics together with recordings of selected performances of individual singer-songwriters. This boxset contains a performance of ‘Amore che vieni amore che vai/Love which comes, love which goes’ (1966) from 1969. Here, the stage is empty, with no scenery or supporting musicians. De André in this instance does not accompany himself on his guitar. He walks around the stage, appearing uncomfortable during his performance, and does not look directly at the camera. In fact, he 
consistently avoids it, instead looking mostly at the floor. For 'La guerra di Piero/Piero's war' (1964), also from 1969, De André does accompany himself on his guitar, and remains seated for the entire performance of the song. However, he continues to avoid looking at the camera. Again, the stage has no scenery or supporting musicians: we can only see the spotlights, and it appears that De André is in fact performing in a back stage area.

There is a trope of a singer-songwriter's performance here which is common to both Brassens and De André: their style serves to focus the audience's attention on them, and they then appear awkward and indeed nervous under such scrutiny. The stage is practically devoid of any distractions, and the spotlight always remains on the singer-songwriter. Thanks to the naturalness and awkwardness that the two singer-songwriters exhibit whilst on stage, we could be led to believe that theirs are authentic performance, revealing the singersongwriters' own personalities and character flaws. Yet these elements are in fact staged, presented by a persona behind which ‘the real' Brassens and De André can hide. But as the audience, we should never be aware of this artifice. In his description of performance art, Frith explains that "the term "performance" defines a social - or communicative - process. It requires an audience and is dependent, in a sense, on interpretation: it is about meanings. To put this another way, performance art is a form of rhetoric, a rhetoric of gestures' (1998: 205). Although Frith is not talking specifically about performance in popular music here, his argument can usefully be applied to this area, particularly in the cases of chanson (as represented by Brassens) and the canzone d'autore (as represented by De André). In these contexts, performance is in fact a physical manifestation of the genre rules which govern conceptualisations of authenticity and quality, deciding what is and is not acceptable when it comes to the performance of the two song forms. In the cases of chanson (as represented by Brassens) and the canzone d'autore (as represented by De André), these performances are 
seen as a physical manifestation of the genre rules which govern conceptualisations of authenticity and quality. The lack of scenery and props, the singer-songwriters' gestures (or lack thereof) and even their physical appearance, to an extent, all perpetuate the rhetoric of the genres. However, these distinguishing performance elements also feed back into the rhetoric itself, serving to create new rules and further develop others. By following the genre rules, the singer-songwriters' performances are legitimised and then codified as a set of rules for subsequent singer-songwriters to follow, in order to be legitimised themselves.

\section{Brel and Gaber}

But this legitimation process becomes more problematic when we consider singersongwriters such as Jacques Brel and Giorgio Gaber who are more obviously performers and entertainers. This is not to say that Brassens and De André are not performers or entertainers but rather that this aspect of Brel and Gaber is highlighted more frequently, with the result that they are often perceived as lesser singer-songwriters than their compatriots. However, Brel and, arguably to a lesser extent, Gaber, are also perceived as exemplary singersongwriters within their respective genres. So what does this mean for the constitutive discourses of the two genres which devalue performance and entertainment and promote the literary aspects of songwriting?

Brel's performances reveal his sense of theatricality and awareness of the need to put on a show and entertain his audience, not merely sing his songs. In reference to Brel, Poole points out that 'the chansonnier [...] is often the one performer of the one-man show he has himself created. He may choose, as did Georges Brassens, to accompany his singing with the playing of an instrument. And he may choose, as did Jacques Brel, rather to become instrument' (2004: vii). It is for this reason, Poole argues, that Brel can be seen as an homme-théâtre. She 
goes on to explain that 'Brel's work is as though welded to his voice and to his stage

presence, the latter best characterised as larger than life' (Poole 2004: xv), and according to her analysis, the intensity which Brel's songs embody is magnified in his performances. This is supported by Pierre Berruer, who explains that

Jacques Brel, désormais, est non seulement un auteur-compositeur mais également un étonnant interprète qui mord dans les mots, chante avec sa gueule et tout son corps, fait vivre ses textes en effaçant les éventuelles imperfections d'écriture. De plus, il a vite compris qu'un tour de chant ne doit pas seulement son succès à la qualité des œuvres qu'il contient mais autant à l'équilibre de la soirée, à l'alternance de chansons 'à gestes', de chansons rythmées et de textes et mélodies plus calmes, apportant comme une ponctuation dans un spectacle conduit crescendo. (Berruer 1983: 61)

[Henceforth, Jacques Brel is not only a singer-songwriter but also an astonishing performer who bites into the words, who sings with his face and the whole of his body, who makes his texts come alive by erasing the possible imperfections in the writing. In addition, he has been quick to understand that a song recital owes it success not only to the quality of the words it contains but also to the balance of the programme, which alternates songs with actions and highly rhythmic songs with calmer words and melodies, to allow a break in an ever-intensifying show.]

A successful performance must be carefully constructed, from the choice and order of specific songs to the facial expressions and gestures of the performer. Brel's performances show that he was indeed aware of this artifice. It is the construction of the performances which serves to magnify the intensity of Brel's songs.

When on stage, Brel usually allows no time for introductions between each of his songs, and chooses to perform dressed in a suit and tie. The lighting is often slightly different for each of his songs, depending on their content (if emotional intensification in a song is sought, for example, the lighting will often reflect this). Brel is also well-known for using gestures, changes in tone of voice and volume and exaggerated facial expressions to similar effect. He also often adopts a different persona for each of his songs, taking on the role of the songs' principal character(s), in order to engage and entertain his audience. By the end of his performances, it is easy to see how hard Brel has worked because of the amount that he has perspired. Adeline Cordier refers to the physicality of Brel’s (and indeed Brassens’s) 
performances, pointing out that many of the review articles published about their shows contained physical descriptions of their voices, bodies, sweat and even spit. She explains that

Critics and journalists often compared the singer-songwriters to craftsmen whose sweating was the result of hard work. Sweating was not unusual for a singer, but it is important to remark, however, that singer-songwriters do not sweat in the same way as rock stars; rock stars sweat because they move and dance, whereas singersongwriters do so as the result of what appears to be a creative effort. (Cordier 2009: 410)

Whilst Brel does move around during his performances, they are certainly not those of a rock star. In a way, then, his performance in fact conforms to the public expectations of what a singer-songwriter's recital ought to be and is interpreted from inside the genre's discourse, which then serves to create Brel, along with Brassens and Ferré, as the paradigms of the genre. With particular reference to Brel, Peter Hawkins points out the dramatic, even theatrical qualities of his work, explaining that

Like Piaf, Brel is able to turn each song into a microcosm of the human condition, a mini-drama with tragic, ironic or comic resonances which remain accessible to a popular audience and yet achieve a sense of universal significance. The difference is that Brel is largely responsible for the whole artistic conception of the song and its treatment, which Piaf was not; the form becomes a vehicle for a very personal vision of the world which transcends individual songs, and gives Brel's material a meditative value comparable to that of Brassens. (Hawkins 2000: 140)

In a way, Brel becomes the stage for these mini-dramas, using his body and voice to tell the story, act out the different roles and ultimately involve the audience in the re-enactments of his songs' narratives.

Like Brel, Gaber is also renowned for '[la] sua energia e [la] sua fisicità sul palcoscenico’ (Bernardini 2002: xiii) [his energy and physicality on stage]. As the proponent of the teatrocanzone (that is, the infusion of a performative, theatrical aspect with the world of song), it is perhaps only natural that Gaber should be an accomplished performer and keenly aware of the need entertain his audience. In his performances from the late 1960s and early 1970s, available on the Giorgio Gaber boxset released by the Parole e canzoni series, Gaber is 
dressed smartly, wearing a suit and tie for the majority of the time. He is energetic and dynamic whilst on stage, using gestures, some of them exaggerated, together with different facial expressions and tones of voice to involve the audience and to encourage their participation in his routine.

But Gaber himself is aware that his performances are staged, as he provides a commentary of his performance of 'Non arrossire/Don’t blush' (1969), looking back from a distance of nearly thirty years. In this, he points out the falseness of his facial expressions and gestures, which are intended to mimic those of the lovers who are the principal characters of this song. Instead of the smiles representing the happiness of the lover, Gaber the commentator ironically suggests that he was smiling because he could not remember the next line of the song. His commentary suggests an element of awkwardness in the performance of which we as the viewers would otherwise remain ignorant. This is reinforced during the bridge, when Gaber walks away from the microphone, hand in pocket, and then runs his other hand through his hair. Whilst this at first appears rehearsed, Gaber's commentary explains that, in fact, he did not know what to do at this point in the song. He laughs at his own actions, trying to underline the apparent spontaneity, naturalness and unease of Gaber as a performer. His performances and the later commentary reveal that, above all else, Gaber is aware of the need to entertain his audience. This is what Massimo Bernardini suggests when he explains that, when performing, Gaber 'intende ripagare la gente che lo ha scelto con una serata di emozioni coinvolgenti, contagianti, divertenti’ (2002: xvi) [intends to repay in full the people who have chosen to come to listen to him by giving them an evening full of enchanting, contagious emotion and fun]. In addition to this, the way in which Gaber introduces the song 'Suona chitarra' in the Parole e canzoni collection reveals the extent to which he understands his role as a singer-songwriter as often equating to that of entertainer. He states that: 
Noi cantanti siamo in una professione un po' strana che a prima vista può sembrare anche piuttosto libera, piuttosto indipendente, anche se ha determinate limitazioni di libertà. Per esempio, la televisione stessa molte volte si inserisce nelle nostre canzoni con dei (posso dirtelo) dei [sic] tagli di censura [...] e poi i nostri discografici anche ci limitano in quanto preferiscono che noi ci diamo dei pezzi molto facili, molto richiabili senza tanti problemi in modo che arrivino più facilmente al pubblico. Ma un'ultima limitazione di libertà che forse vi giungerà più inaspettata è quella che ci arriva da voi, dal pubblico che molto spesso ci desidera, ci preferisce però in una maniera diversa da quella con la quale noi vorremmo presentarci sul palcoscenico. Certo sarebbe forse troppo bello poter cantare esclusivamente le canzoni che ci piacciono di più. (Gaber n.d.)

[We singers are in a pretty strange profession which at first glance can also seem fairly free, fairly independent, even if this freedom has determined limitations. For example, our songs appear many times on television with (I can tell you) omissions due to the censors [...] and our records are also limited because they prefer us to give them really easy pieces, which can be memorised without too many problems so that they easily reach the public. But another limitation of our freedom, which you would perhaps not expect, is the one that comes from you, the audience, who want [to listen to] us and prefer [to listen to] us, but in a different way to that which we ourselves would like to present on stage. Certainly, it would perhaps be too good to be able to sing exclusively the songs which we like the most.

He then proceeds to sing the song 'Suona chitarra/Play your guitar' (1970) which is met with much applause from his complicit audience, who seem at this point to appreciate Gaber's awareness of his own duality (although they may equally just be enjoying his choice of song).

The refrain states:

E allora

Suona chitarra falli divertire

Suona chitarra non farli mai pensare

Suona chitarra mia

E tutti in allegria. (ll. 15-19)

[And so

Play the guitar, entertain them

Play the guitar, never make them think

Play my guitar

And everyone will be happy.]

As the song's dynamics build towards the end, and as Gaber encourages his audience to sing along, he changes the pronoun in the refrain from 'li' [them] to 'ci' [us], and so the inclusivity of his gestures is mirrored by the lyrics of the song. Yet the irony of what Gaber is saying may well be lost to a certain extent on his audience, who applaud his self-awareness 
whilst continuing to enjoy his performance. In a similar way, the commentary Gaber provides for 'Non arrossire' underscores his awareness of his audience: even though he is talking about, and often belittling, his own act on stage, he does so by being humorous and selfdeprecating, thus again entertaining the audience listening to his commentary. As a consummate performer, Gaber is clearly aware of his audiences' needs and is able to respond to them accordingly, appearing to thrive on his audiences' enjoyment.

\section{Conclusion}

Consummate performers such as Brel and Gaber who are able to present a range of characters, settings, problems and emotions which engage the audience do not seem to fit neatly in the conceptualisation of their respective genres as primarily literary and/or artistic. The physicality of the on-stage performances of Brel and Gaber, and the clever construction of the order of their programmes suggest an awareness of their own popularity and of the resultant need to entertain their audiences. It would therefore seem that the notions of performance, popularity and persona which Brel and Gaber embody contest the ways in which critical discourse has conceptualised their respective genres. It could even be argued that the idea of Brassens and De André as performers also challenges this discourse. The fact that the rhetoric surrounding the two men focuses on the elements of their performance which are most removed from the notions of commerce and entertainment serves to recuperate them as paradigms for their genres.

Significantly, the rules of chanson and the canzone d'autore have been conceived by the constitutive critical discourses of the two genres. These rules conceptualise the song forms as literary, artistic, poetic and not commercial or industrial. But such rules must be bent or even ignored when we consider the importance of the singer-songwriters' performances. This is 
not to say that all discourse surrounding chanson and the canzone d'autore overlooks the notion of performance: the popular conceptualisation of singer-songwriters, such as that represented by newspaper review articles or fan and audience responses, reveals that performance is an important element in the appreciation and consumption of these genres. As far as these French and Italian artists are concerned, then, another look at these singersongwriters in their natural habitat - not the recording studio, or the study, but on the stage within the context of the critical discourse of chanson and canzone d'autore, enables us to explore the complexities and restrictions of this discourse, and of its conceptualisation of these genres. In addition, in the light of those singer-songwriters like Brel and Gaber who, as consummate performers, could be considered to be breaking their genres' rules, perhaps we need to re-evaluate the appropriateness of such conceptualisations of chanson and the canzone d'autore, which foreground the artistic and the literary and overlook the performative, and thus challenge the preconceptions which the labels auteur-compositeurinterprète and cantautore embody.

\section{Bibliography}

Auslander, P. (1999), Liveness: Performance in a Mediatized Culture, London: Routledge.

Bottet, B. and Salachas, G. (1989), Guide de la chanson française contemporaine, Paris: Syros/Alternatives.

Bernardini, M. in Gaber, G. (2002), La libertà non è star sopra un albero, Turin: Einaudi.

Berruer, P. (1983), Jacques Brel va bien. Il dort aux Marquises, Paris: Presses de la Cité.

Cordier, A. (2009), 'Chanson as oral poetry? Paul Zumthor and the analysis of performance', French Cultural Studies, 20:4, pp. 404-18.

Cristiani, F-R. and Leloir, J-P. (2003), Trois hommes dans un salon: Brel, Brassens, Ferré, Paris: Fayard/Éditions du verbe.

Fabbri, F. (2008), 'Il cantautore con due voci' in Alberione, E. and others, Fabrizio De André: Accordi eretici, Milan: Rizzoli, pp. 155-67. 
Frith, S. (1998), Performing Rites: Evaluating Popular Music, Oxford: Oxford University Press.

Galanti, R. (1964), 'Piccola storia della canzone italiana. Gli anni d’oro dei cantautori', Musica e dischi, 24, p. 14.

Haworth, R. (in press) 'Brassens, Brel, Ferré and the Performance of Authenticity in the chanson française’, in Lebrun, B. (ed.), Chanson et Performance: Mise en scène du corps dans la chanson française et francophone, Paris: L’Harmattan. (To press December 2012).

Hawkins, P. (2000), Chanson: The French Singer-Songwriter from Aristide Bruant to the Present Day, Aldershot: Ashgate.

Marny, J. (1965), La Chanson et ses vedettes des troubadours aux Beatles, Paris: Éditions du Centurion.

Poole, S. (2000), Brassens: Chansons, London: Grant \& Cutler.

Poole, S. (2004), Brel and Chanson: A Critical Appreciation, Dallas: University Press of America.

Potter, J. (n.d.), 'Singer-songwriter', http://0-

www.oxfordmusiconline.com.wam.leeds.ac.uk/subscriber/article/grove/music/46855?q=sing er-

songwriter\&hbutton_search. $x=0$ \&hbutton_search. $y=0$ \&hbutton_search=search\&source $=$ omo _t237\&source=omo_gmo\&source=omo_t114\&search=quick\&pos=1\&_start=1\#firsthit.

Accessed 13 November 2011.

Shuker, R. (2002), Popular Music: The Key Concepts, London: Routledge.

Vernillat, F. and Charpentreau, J. (1971), La Chanson française, Paris: Presses Universitaires de France.

White, A. (1987), Lost in Music: Culture, Style and the Musical Event, London: Routledge \& Kegan Paul.

\section{Videography}

Brassens, G. (2004), Elle est à toi cette chanson, 3 vols., DVD 982 004-0, Universal/Mercury

Brel, J. (2003), Brel: Comme quand on était beau, 3 vols., DVD 980 832-0,

Universal/Barclay

De André, F. (n.d.), Fabrizio De André. Parole e canzoni. A cura di Vincenzo Mollica, Einaudi Stile libero/Video (Video).

Gaber, G. (n.d.), Giorgio Gaber. Parole e canzoni. A cura di Vincenzo Mollica, Rai Trade (Video). 


\footnotetext{
${ }^{1}$ Although Jacques Brel was in fact Belgian, he has come to be represented as the best of chanson production in France, along with Georges Brassens and Léo Ferré. For critics, the notions of quality and authenticity within chanson are closely associated the works of this trio. Brel's Belgian national identity is overlooked by these critics, or, rather, it is co-opted in order to present him as a representative of French ideals for chanson. The fact that Brel moved to France very early in his career, in order to establish himself as a singer-songwriter, signed with French record labels and remained in France for most of his life enables this cooption.

${ }^{2}$ In the cases of France and Italy during this period, the majority of singer-songwriters were male. A gendered reading of performance does not form part of the analysis of this article, but would constitute a useful expansion of this research field. I do consider the conceptualisation of masculinity within the chanson française elsewhere (see R. Haworth, 'Brassens, Brel, Ferré and the Performance of Authenticity in the chanson française')
} 